\title{
KIF4A Gene
}

National Cancer Institute

\section{Source}

National Cancer Institute. KIF4A Gene. NCI Thesaurus. Code C63505.

This gene is involved in a variety of important cellular processes, such as cell division. 